\title{
Gambaran Golongan Sekretor dan Nonsekretor yang Diperiksa Melalui Saliva Mahasiswa Pendidikan Dokter
} Fakultas Kedokteran Universitas Andalas

\author{
Alqadri ${ }^{1}$, Zelly Dia Rofinda ${ }^{2}$, Rika Susanti ${ }^{3}$
}

\begin{abstract}
Abstrak
Kasus kriminal di Indonesia setiap tahunnya cenderung mengalami peningkatan. Salah satu identifikasi yang dilakukan untuk membantu mengetahui pelaku kriminal adalah dengan memeriksa golongan darah. Golongan darah dapat diperiksa langsung bila di tempat kejadian perkara (TKP) terdapat noda atau bercak darah, tetapi dalam beberapa kasus kriminal biasanya cairan yang ditemukan adalah air ludah (saliva) dalam bentuk basah ataupun kering. Pemeriksaan golongan darah melalui saliva bisa dilakukan apabila orang tersebut termasuk golongan sekretor tetapi tidak bisa diperiksa apabila termasuk golongan nonsekretor. Tujuan penelitian ini adalah mengetahui persentase golongan sekretor dan nonsekretor mahasiswa pendidikan dokter Fakultas Kedokteran Universitas Andalas. Ini merupakan penelitian deskriptif observasi dengan desain cross sectional. Populasi dalam penelitian ini adalah mahasiswa pendidikan dokter Fakultas Kedokteran Universitas Andalas sebanyak 54 orang. Cara pengambilan sampel adalah dengan simple random sampling. Data mengenai golongan sekretor dan nonsekretor didapatkan melalui pemeriksaan saliva dengan metode absorpsi inhibisi. Hasil penelitian ini menunjukkan bahwa 42 orang (78\%) termasuk golongan sekretor dan 12 orang (22\%) termasuk golongan nonsekretor. Berdasarkan hasil penelitian ini dapat disimpulkan bahwa distribusi golongan sekretor lebih besar daripada golongan nonsekretor pada mahasiswa pendidikan dokter Fakultas Kedokteran Universitas Andalas.
\end{abstract}

Kata kunci: nonsekretor, saliva, sekretor

\section{Abstract}

Criminal cases in Indonesia tends to increase each year. One of the identification is being to help find criminal is by checking the blood type. Blood type can be checked directly on the scene when there are stains or spots of blood, but in some cases the criminal is usually found saliva in wet or dry form. Blood type through saliva can be done if the person have secretor but can not be checked if including non-secretor. The objective of this study was to determine the percentage of secretors and non-secretor class on the student Medical Faculty of Andalas University. This study was an observational descriptive study with cross-sectional design. The population were 54 students Medical Faculty of Andalas University which choosen by simple random sampling. Data on group secretor and nonsecretor saliva obtained through examination of the absorption inhibition method. The results showed that 42 people (78\%) that are secretor and 12 people (22\%) including non-secretors. Based on these results it can be concluded that the distribution of secretor groups larger than non-secretors in the student of Medical Faculty Andalas University.

Keywords: non-secretor, saliva, secretor

Affiliasi penulis: 1. Pendidikan Dokter FK UNAND (Fakultas Kedokteran Univertsitas Andalas Padang), 2. Bagian Patologi Klinik FK UNAND, 3. Bagian Forensik FK UNAND

Korespondensi: Alqadri, email:qoikz@yahoo.com, Telp: 085263360000

\section{Pendahuluan}

Kasus kriminal di Indonesia setiap tahunnya cenderung mengalami peningkatan. Menurut Data Badan Pusat Statistik (BPS) yang diperoleh dari 
Markas Besar Kepolisian Negara Republik Indonesia (MABES POLRI), pada tahun 2010 diketahui jumlah tindak pidana di Indonesia adalah 332.249 kasus dan mengalami peningkatan pada tahun 2011 menjadi 347.605 kasus. Di Provinsi Sumatera Barat juga tercatat terjadi peningkatan jumlah tindak pidana dari 10.819 kasus pada tahun 2010 menjadi 11.695 kasus pada tahun 2011. Tindak pidana adalah perbuatan yang dilarang oleh suatu aturan hukum dan diberi sanksi bagi barang siapa yang melanggar aturan tersebut. $^{1,2}$

Orang yang melakukan tindak pidana disebut pelaku kriminal atau tersangka. Untuk mencari pelaku kriminal harus dilakukan identifikasi. Identifikasi menurut KBBI adalah tanda kenal diri atau bukti diri. Identifikasi berguna untuk menentukan identitas pelaku untuk kepentingan hukum dalam suatu proses peradilan dan menegakkan kebenaran. Salah satu identifikasi yang dilakukan untuk membantu mengetahui pelaku kriminal adalah dengan memeriksa golongan darah. ${ }^{3-6}$

Golongan darah dapat diperiksa langsung bila di tempat kejadian perkara terdapat noda atau bercak darah, tetapi dalam beberapa kasus kriminal seperti pemerkosaan, perampokan dan gantung diri kadangkadang tidak terdapat noda atau bercak darah pada tempat kejadian perkara (TKP). Di TKP biasanya cairan yang ditemukan adalah air ludah (saliva) dalam bentuk basah ataupun kering seperti bekas dari tanda gigitan, puntung rokok, sisa makanan, tutup amplop, peralatan gigi, tusuk gigi atau barang lainnya yang terkontaminasi dengan saliva. ${ }^{4,5,7}$

Saliva merupakan cairan tersering yang ditemukan pada tubuh korban kriminal dan juga sebagai barang bukti tersering yang terdapat di TKP. Saliva yang ditemukan ini juga bisa digunakan untuk mencari golongan darah dari pelaku yang dicurigai. Pemeriksaan golongan darah melalui saliva bisa dilakukan hanya pada orang yang berstatus golongan sekretor. Golongan sekretor adalah orang yang mengeluarkan antigen golongan darah yang identik dengan sel darah merahnya pada semua cairan tubuhnya seperti saliva dan sperma. ${ }^{8-11}$

Analisis saliva ini bisa dibuat sediaan ulasnya apabila terdapat bekas air ludah pada tubuh korban misalnya pada bekas gigitan ditubuh korban atau pada sisa makanan yang dimakan oleh pelaku di TKP. Apabila saliva tersebut berasal dari orang bergolongan darah sekretor maka dapat diketahui golongan darahnya dari saliva tersebut dengan menggunakan metode absorpsi inhibisi, tetapi apabila saliva tersebut berasal dari orang yang bergolongan nonsekretor maka tidak dapat ditentukan golongan darahnya dengan metode absorpsi inhibisi. ${ }^{12-14}$

Pemeriksaan golongan darah dengan metode absorpsi inhibisi adalah pemeriksaan golongan darah secara tidak langsung melalui material selain darah yang berasal dari cairan tubuh misalnya pada saliva, sperma, cairan lambung dan cairan lainnya. Pemeriksaan golongan darah dengan metode absorpsi inhibisi ini prinsipnya sama dengan pemeriksaan golongan darah $\mathrm{ABO}$ yang biasa dilakukan, tetapi dengan metode berbeda. Pemeriksaan golongan darah $\mathrm{ABO}$ merupakan tipe penggolongan darah yang paling sering dipakai dalam studi populasi genetik dan identifikasi seorang individu pada kasus kriminal sampai saat ini. ${ }^{7,10,15}$

Menurut penelitian laboratorium kedokteran kepolisian di Jakarta bahwa dari sejumlah anggota kepolisian yang diteliti $75 \%$ adalah golongan sekretor, sedangkan dari data populasi bahwa manusia didunia ini $85 \%$ adalah golongan sekretor. ${ }^{13,16}$

Berdasarkan penelitian lain di Jepang dari 91 mayat yang diperiksa golongan darah melalui kelenjar ludahnya, 70 kasus diklasifikasikan sebagai tipe sekretorik karena dapat diketahui golongan darahnya dan 21 sebagai tipe nonsekretorik. ${ }^{17}$

Oleh karena itu, perlu untuk mengetahui informasi tentang distribusi golongan sekretor dan nonsekretor di setiap kelompok populasi masyarakat untuk memudahkan dan membantu pihak yang berwenang dalam mengidentifikasi pelaku tindakan kriminal.

\section{METODE}

Penelitian ini dilakukan di Laboratorium sentral Fakultas Kedokteran Universitas Andalas dari Januari 2013 sampai April 2014. Subjek adalah mahasiswa pendidikan dokter Fakultas Kedokteran Universitas Andalas. Pengambilan sampel menggunakan teknik simple random sampling. 
Hasil

Dari 54 sampel yang dilakukan pemeriksaan saliva ditemukan 42 sampel (78\%) adalah termasuk golongan sekretor dan 12 sampel (22\%) adalah termasuk golongan nonsekretor.

Tabel 1. Karakteristik subyek penelitian

\begin{tabular}{lcc}
\hline Karakteristik & $\mathbf{n}$ & (\%) \\
\hline Jenis Kelamin & 28 & 52 \\
$\quad$ Pria & 26 & 48 \\
Wanita & & \\
Umur & & \\
$\quad$ 18-23 tahun & 54 & 100 \\
& & \\
Golongan darah & & \\
$\quad$ A & 24 & 44 \\
B & 20 & 37 \\
AB & 10 & 19 \\
\hline Total & 54 & 100 \\
& & \\
\hline
\end{tabular}

Berdasarkan Tabel 1 diatas diketahui bahwa sampel pria adalah 28 orang (52\%) dan wanita 26 orang (48\%). Umur sampel 18-23 tahun. Sampel bergolongan darah A adalah 24 orang (44\%), B adalah 20 orang (37\%) dan $A B$ adalah 10 orang (19\%).

Tabel 2. Gambaran golongan sekretor dan nonsekretor golongan darah $A, B$ dan $A B$

\begin{tabular}{cccc}
\hline $\begin{array}{c}\text { Golongan } \\
\text { Darah }\end{array}$ & $\mathbf{N}$ & Sekretor(\%) & Nonsekretor(\%) \\
\hline A & 24 & $19(79 \%)$ & $5(21 \%)$ \\
B & 20 & $15(75 \%)$ & $5(25 \%)$ \\
AB & 10 & $8(80 \%)$ & $2(20 \%)$ \\
\hline Total & 54 & $42(78 \%)$ & $12(22 \%)$ \\
\hline
\end{tabular}

Berdasarkan Tabel 2 diatas diketahui bahwa sampel bergolongan darah $A$ yang termasuk golongan sekretor adalah 19 orang (79\%) dan nonsekretor adalah 5 orang (21\%), sampel yang bergolongan darah B yang termasuk golongan sekretor adalah 15 orang $(75 \%)$ dan nonsekretor 5 orang (25\%) dan sampel bergolongan darah $A B \quad 8$ orang (80\%) termasuk golongan sekretor dan 2 orang (20\%) termasuk golongan nonsekretor.
Tabel 3. Gambaran golongan sekretor dan nonsekretor terhadap jenis kelamin

\begin{tabular}{cccc}
\hline $\begin{array}{c}\text { Jenis } \\
\text { Kelamin }\end{array}$ & $\mathbf{n}$ & $\begin{array}{c}\text { Sekretor } \\
(\%)\end{array}$ & $\begin{array}{c}\text { Nonsekretor } \\
(\%)\end{array}$ \\
\hline Pria & 28 & $20(71 \%)$ & $8(29 \%)$ \\
Wanita & 26 & $22(85 \%)$ & $4(15 \%)$ \\
\hline Total & 54 & $42(78 \%)$ & $12(22 \%)$ \\
\hline
\end{tabular}

Berdasarkan Tabel 3 diatas diketahui bahwa sampel laki-laki 20 orang (71\%) adalah golongan sekretor dan 8 orang (29\%) adalah golongan nonsekretor. Sampel wanita 22 orang (85\%) adalah golongan sekretor dan 4 orang (15\%) adalah golongan nonsekretor.

Tabel 4. Gambaran golongan sekretor dan nonsekretor

\begin{tabular}{ccc}
\hline Golongan & $\mathbf{n}$ & $\%$ \\
\hline Sekretor & 42 & 78 \\
Nonsekretor & 12 & 22 \\
\hline Total & 54 & 100
\end{tabular}

Berdasarkan Tabel 4 diatas diketahui bahwa golongan sekretor sebanyak 42 orang (78\%) dan golongan nonsekretor sebanyak 12 orang (22\%).

Hasil penelitian ini sejalan dengan penelitian yang dilakukan di laboratorium kedokteran kepolisian di Jakarta bahwa dari sejumlah anggota kepolisian yang diteliti $75 \%$ adalah golongan sekretor. Begitu juga penelitian yang dilakukan di Jepang oleh Takahashi (2011) dari 91 mayat yang diperiksa golongan darah melalui kelenjar ludahnya 70 mayat (77\%) adalah golongan sekretor dan 21 mayat (23\%) adalah nonsekretor. ${ }^{7,17}$

Istilah sekretor dan nonsekretor diklasifikasikan berdasarkan kemampuan individu untuk mengeluarkan antigen golongan darah $\mathrm{ABO}$ dalam cairan tubuhnya seperti saliva, sperma keringat, air mata dan sekresi lendir gastrointestinal. Tipe sekretor adalah individu bergolongan darah $A, B$ atau $A B$ yang mengeluarkan antigen golongan darah $\mathrm{ABO}$ pada cairan tubuhnya seperti saliva, sperma, keringat, air mata dan sekresi lendir gastrointestinal, sedangkan tipe nonsekretor adalah individu bergolongan darah $A$, $B$ atau $A B$ yang tidak mempunyai antigen golongan 
darah $\mathrm{ABO}$ dalam saliva, sperma, keringat, air mata dan sekresi lendir gastrointestinal. ${ }^{18-21}$

Golongan sekretor ini dapat diketahui dengan 2 metode yaitu absoprsi inhibisi dan metode absorpsi elusi. Absorpsi inhibisi adalah metode pemeriksaan golongan sekretor yang dilakukan apabila barang bukti yang ditemukan adalah dalam bentuk cairan tubuh selain darah, sedangkan metode absorpsi ilusi adalah pemeriksaan golongan sekretor yang dilakukan apabila barang bukti yang ditemukan dalam bentuk jaringan keras tubuh manusia seperti tulang, rambut dll. ${ }^{7,22-24}$

Golongan sekretor ini dapat diperiksa golongan darah melalui saliva karena adanya pengaruh gen sekretor (Se). Gen Se ini terletak pada kromosom 19. Gen Se mengkode enzim fucosyltransferase tertentu yang terletak di dalam epitel jaringan sekretorik seperti kelenjar ludah, keringat, air mata dan sekresi lendir gastrointestinal sehingga membuat kelenjar-kelenjar tersebut menghasilkan antigen golongan darah yang sama dengan antigen eritrosit mereka tapi dalam bentuk larut air (soluble). Sedangkan golongan nonsekretor memiliki gen se. Gen ini tidak mampu menghasilkan bentuk antigen yang larut sehingga tidak menghasilkan antigen golongan darah pada cairan tubuhnya. ${ }^{12,16,25-28}$

Distribusi golongan sekretor dan nonsekretor dari populasi manusia adalah $85 \%$ adalah golongan sekretor dan $15 \%$ adalah golongan nonsekretor. ${ }^{7,29}$

\section{KESIMPULAN}

Distribusi golongan sekretor lebih banyak daripada golongan nonsekretor. Distribusi golongan sekretor pada mahasiswa pendidikan dokter Fakultas Kedokteran Universitas Andalas adalah 78\% dan golongan nonsekretor adalah $22 \%$.

\section{UCAPAN TERIMA KASIH}

Terima kasih kepada semua pihak yang telah memberikan bantuan dan motivasi dalam penelitian ini, sehingga dapat selesai pada waktunya.

\section{DAFTAR PUSTAKA}

1. Bonger WA. Pengantar Tentang kriminologi. Jakarta: Pustaka Sarjana; 2003.
2. Chazawi A. Pelajaran hukum pidana bagian 1 . Jakarta: PT Raja Grafindo Persada; 2002.

3. Schroeder P. Determining secretor status. [serial online] 1994 (diunduh 17 september 2013) Tersedia dari: URL: HYPERLINK http://faculty. madisoncollege.edu/mljensen/BloodBank/Lab Man ual/determining secretor status.htm

4. Amerongen AVN. Ludah dan kelenjar ludah. Yogyakarta: Gadjah Mada University Press; 1991.

5. Auerkari El. On ABO blood grouping based on tooth material. [serial online] 2003 (diunduh 05 Mei 2013). Tersedia dari: URL: HYPERLINK http://staff.ui.ac.id/system/files/users/elza.ibrahim/p ublication/ob-elza2.pdf

6. Blackmun HA, Helpern M. Forensic medicine vol 2 physical Trauma. Philadelphia: WB Suander Company;1977.

7. Lukman D. Buku IImu kedokteran gigi forensik jilid 2. Jakarta: Sagung Seto; 2006.

8. Campi C, Escovich L, Moreno A, Racca L, Cotorruelo C, Biondi C. Expression of the gene encoding secretor type galactoside 2 a fucosyltraferase (FUT2) and $\mathrm{ABH}$ antigens in patients with oral lesions. Med Oral Patol Oral Cir Bucal. 2012; 17(1):e63-8. (diunduh 19 Agust 2013); Tersedia dari: URL: HYPERLINK http://www.ncbi.nlm.nih. gov/pubmed/2215767

9. Harry H. Dasar-dasar genetika manusia. Edisi ke3. Yogyakarta: Gadjah Mada University Press; 1994.

10. Robert JAF, Pembrey ME. Pengantar Genetika kedokteran (terjemahan). Jakarta: EGC; 1995.

11. Dorland WAN. Kamus kedokteran Dorland. Edisi ke-29. Jakarta: EGC: 2008.

12. Pai AC. Dasar- dasar genetika. Jakarta: Erlangga; 1987.

13. Kusumasari PM. Studi perbandingan hasil pemeriksaan golongan darah terhadap sampel saliva segera dan sampel saliva yang disimpan selama 1 jam pada temperatur $7^{\circ} \mathrm{C}$. [skriprsi]. Jakarta: Fakultas Kedokteran gigi Universitas Indonesia; 2007.

14. Laura D. Blood groups and red cell antigens; chapter 5 the ABO blood group. National Center for Biotechnology Information. [serial online] 2005 (diunduh 09 November 2013). Tersedia dari : 
URL: HYPERLINK http://www.ncbi.nlm.nih.gov/ pubmedhealth/PMH0003826/2005

15. Sastroasmoro $S$, Ismael $S$. Dasar-dasar metode penelitian klinis. Edisi ke-2. Jakarta: Sagung Seto: 2002.

16. Sherwood L. Fisiologi manusia (terjemahan). Jakarta: EGC;2001.

17. Takahashi M, Kamiyama S. Immunohistological studies on $\mathrm{ABH}$-activities in secretory cells of human major salivary glands--correlation between $\mathrm{ABH}$-activities in the secretory cells and secretornonsecretor. [serial online] 2011 (diunduh 11 Oktober 2013) Tersedia dari: URL: HYPERLINK http://www.ncbi.nlm.nih.gov/pubmed/3914150

18. Ganong WF. Fisiologi kedokteran (terjemahan). Edisi ke-20. Jakarta:EGC; 2001.

19. Almeida, Del Vigna P De, et al. Saliva composition and functions a comprehensive. the journal of contemporary dental practice. Jaypeejournals. 2008 March; 9(3):72-80 (diunduh 7 july 2013);. Tersedia dari: URL: HYPERLINK http://www. jaypeejournals.com/eJournals/ShowText.aspx?ID= 1867\& Type $=$ FREE\&TYP $=$ TOP\&IN $=$ eJournals $/ \mathrm{ima}$ ges/JPLOGO.gif\& IID=159\&isPDF=YES

20. Emery, Alan EH. Dasar-dasar genetika kedokteran. Yogyakarta: Yayasan Essentia Medica;1992.

21. Wiley John dan Sons Ltd. Molecular forensics. The Atrium, Southern Gate, Chichester, West Sussex: England; 2007.hIm.347.

22. Yatim W. Genetika. Bandung: Tarsito: 1996.

23. Guyton AC, Hall JE. Fisiologi kedokteran (terjemahan). Jakarta: EGC; 2006.
24. Motghare $\mathrm{P}$, et al. Efficacy and accuracy of ABO blood group determination from saliva. Journal of Indian Academy of Oral Medicine and Radiology. 2011 July;23(3):163-7 (diunduh 7 February 2013). Tersedia dari: URL: HYPERLINK http://www. jaypeejournals.com/eJournals/ShowText.aspx?ID= 2264\&Type=FREE\&TYP=TOP\&IN= eJournals/ima ges/JPLOGO.gif\& $\| \mathrm{D}=189$ \&isPDF=YES

25. Goodnough LT. Transfusion medicine. Dalam: Goldman L, Ausiello D, editor (penyunting). Cecil Medicine. [serial online] 2007 (diunduh 09 November 2013). Tersedia dari: URL: HYPERLINK http://www.ncbi.nlm.nih.gov/pubmedhealth/PMH00 $\underline{03826 / 2005}$

26. Saxena $S$, et al. Experimental studies of forensic odontology to aid in the identification process. J Forensic Dent Sci. 2010 July;2(2):69-76. (diunduh 8 Agust 2013).Tersedia dari: URL: HIPERLINK http://www.ncbi.nlm.nih.gov/pmc/articles/PMC3125 956/

27. Mahabalesh S, Premalatha K. Original research paper $A B O$ Blood Grouping from tooth material. Journal Indian Acad Forensic Med. 2001;32(4) (diunduh 26 March 2013). Tersedia dari: URL: HYPERLINK http://medind.nic.in/ial/t10/i4/jalt 10i4p336.pdf

28. Stedman. Kamus ringkas kedokteran. Jakarta: EGC: 2001.

29. Lukman D. Buku ilmu kedokteran gigi forensik jilid 1. Jakarta: Sagung Seto: 2006. 